\title{
Työväen sivistystyö postmodernin kynnyksellä
}

\section{Maria-Liisa Marjamäki - Pertti Rantanen (toim.): Tulemisen tilassa. Näkökulmia työväen si- vistystyöhön postmodernin kynnyksellä. TSL 1995.}

Työväen Sivistysliiton julkaisema kirja Tulemisen tilassa sisältää alaotsikon mukaisesti näkökulmia työväen sivistystyöhön postmodernin kynnyksellä. Teos on tarkoitettu työväenliikkeen sivistyskeskustelun herättäjäksi ja avaajaksi, mutta se on kiinnostava ja merkityksellinen vapaan sivistystyön kannalta yleisemminkin. Tämä koskee varsinkin artikkeleita, joissa arvioidaan sivistystyön muuttuvaa toimintaympäristöä ja tulevaisuuden tehtäviä.

Leena Ahteenmäki-Pelkonen (Itseohjautuvuus, autonomia, vapaa sivistystyö) käsittelee moderniin aikuiskoulutukseen kuuluvan itseohjautuvuuden suhdetta vapaaseen sivistystyöhön. Hän esittää tavanomaisen yksilökeskeisen itseohjautuvuuden rinnalle useammankin yhteisöllisen itseohjautuvuuden mallin. Hyvin argumentoidun kehittelyn lopputulos, toimintaperusteita arvioiva itseohjautuvuus, on vapaan sivistystyön oman toiminnan arvioinnin kannalta vähintäänkin kiinnostava.

Toisaalta kirjoittaja kysyy, onko itseohjautuvuus lainkaan soveltuva termi vahvasti yhteisöllisen sivistystyön kuvaamiseen. Toiminnan subjektihan on kollektiivinen. Puolustan käsitteen käyttämistä. Z.Castrén kirjoitti 1929, että sivistystyön tarkoituksena on "saada hereille ja edistää aikuisten vapaita itsekasvatuspyrkimyksiä". Itseohjautuvuus on lähellä vapaan sivistystyön autonomian käsitettä, joka on alan kuvaamisen kannalta vieläkin tärkeämpi.

Erkki Aho (Tasa-arvon ajatus suomalaisessa aikuiskasvatuksessa) kuvaa seikkaperäisesti, miten aikuiskoulutusta koskeva koulutuspoliittinen näkökulma on kaventunut sitten 1970-luvun alun. Koulutuksen tasa-arvoa koskevat maininnat ovat vähitellen lyhentyneet ja kadonneet niin komiteamietintöjen kuin hallitusohjelmienkin teksteistä. Aikuiskoulutus on välineellistynyt, sen tavoitteeksi on melkein yksinomaisesti noussut taloudellisen kasvun ja kilpailukyvyn vahvistaminen. Muutos on syntynyt yksittäisten päätösten myötä, kysymyksessä on ollut eräänlainen "hidden educational policy".

Ahon antamaa kuvaa täydentävät aikuiskoulutuksen osallistumistutkimusten tulokset. Osallistuminen on kasautuvaa, hyvin koulutetut käyttävät eniten koulutuspalveluja, huonosti koulutetut vähiten. Pertti Rantanen puolestaan esittää jäljempänä tarkemmin arvioitavassa artikkelissaan, että aikuiskoulutuksessa näkyy kansan polarisaatio. Hänen mukaansa ylemmissä asemissa oleville on tarjolla paljon ja monipuolista koulutusta, alemmissa asemissa oleville vähän.

On vaikea uskoa, että aikuiskoulutuksen epätasa-arvo johtuisi ratkaisevalla tavalla tarjonnan vähäisyydestä tai palveluverkoston riittämättömyydestä. Siihen vaikuttaa pikemminkin eri sosiaaliryhmien erilainen suhtautuminen opiskeluun ja kouluttautumiseen. Uskottavilta tuntuvat myös selitykset, että aikuiskoulutustyötä tehdään pitkälle koulutetun keskiluokan ehdoin. Osallistumiskynnys on korkea niille, joiden oppimisen kokemukset ja edellytykset ovat heikot.

Aikuiskoulutuksen tasa-arvon tulevaisuus riippuu viime kädessä siitä, miten pohjoismaisen hyvinvointivaltion arvoille ja periaatteille suomalaisessa yhteiskunnassa käy. Tärkeä tekijä on EU:n 
koulutuspolitiikan välillinen vaikutus pitemmän päälle - sehän palvelee taloudellisen kilpailukyvyn kasvattamista ja uskoa Euroopan oikeuteen olla johtava talousmahti maailmassa.

Kari Kinnusen artikkeli (Työväenliikkeen opistojen kehityksestä) valottaa työväenliikkeen kansanopistojen näkymiä toimintaympäristön syvällisten muutosten keskellä. Kun yhtenäistä työväenliikettä ei enää ole, työväenliikkeen perinteestä rakentuvalle aikuiskoulutuksella ei ole tilausta eikä tulevaisuutta. Ei ole siis yllättävää, että opistot ovat vaikeuksissa ja osa niistä on päätetty lakkauttaa.

Kinnunen esittää muutamia uusia painopisteitä työväenliikkeen opistojen koulutusohjelmiin. Esimerkiksi kasvatus suvaitsevaisuuteen ja toisten kulttuurien ymmärtämiseen, syrjäytyneiden väestöryhmien tarpeista huolehtiminen ja kansainvälistyminen nousevat esille. Silti, kuten kirjoittaja toteaa, koulutussisältöjen suuri yhteiskunnallinen missio jää utuiseksi ja käytännön koulutus saa yhä enemmän samoja sisältöjä ja muotoja kuin muu yleinen aikuiskoulutuskin. Näin ollen opistojen strategian määrittäminen on vaikeaa, mutta Kinnusen artikkelissa ilmenevällä itsekriittisellä ja rohkealla otteella toki mahdollista.

Pertti Rantasen artikkeli (1ryöväen Sivistysliitto jonkin partaalla - arvioita nykytilasta ja tulevaisuuden suunnista) on TSL-keskeisestä ongelmanasettelusta huolimatta liikkeen ulkopuolisenkin lukijan kannalta erityisen mielenkiintoinen. Siinä käsitelty yhdistyslaitoksen murros ja vanhojen kansanliikkeiden kriisi avaavat hyviä kysymyksiä koko järjestöllisen sivistystyön ja opintokeskustoiminnan tilanteen arvioimiseen.

Vanhoille kansanliikkeille on ollut ominaista kollektiivisuuden ja siitä nousevan yksilön turvan korostaminen. Yksilö on jäänyt kollektiivisuuden varjossa heikoksi. Yksilö on kiinnittynyt kansalaisuuteen kollektiivin kautta. Nyt Rantanen lainaa Jari Ehrnroothia: "Yksimielisyys ja sitoutuminen yhteisöön tai yhteiskunnalliseen liikkeeseen ei voi enää auttaa kansalaista rakentamaan omaa elämäänsä nykyaikaisessa yhteiskunnassa", ja vielä John Vikströmiä, jonka mukaan kansalainen haluaa olla oma räätälinsä, kokkinsa ja seppänsä -myös oma opettajansa ja pappinsa.

TSL:ssä on Rantasen artikkelin valossa tehty kaiken kaikkiaan hyvä analyysi sivistystyön toimintaympäristön muutoksesta. Sivullisena ajattelen, että yksilön ja yksilöllisyyden nostaminen sille nykyaikana kuuluvaan arvoon on iso urakka nimenomaan työväenliikkeen piirissä. Kysymys on työväenliikkeen postmodernisoinnin perustasta.

Rantanen toteaa, että opintokeskusten ulkoinen ilme aikuiskoulutusorganisaationa on ollut kehittymätön ja epämääräinen, ja selittää sitä niiden toiminnan painottumiselle valtionavun tekniseen välitykseen opinto- ja sivistystoiminnan sijasta. Suuret toimintaluvut ovat olleet mahdollisia, kun opintokeskukset ovat kirjanneet toiminnakseen kaiken sen jäsen- ja asiakasjärjestöjensä toiminnan, johon ne välittävät valtionapua. Tämän Rantanen näkee seurauksena vuonna 1974 voimaan tulleesta laista, joka levensi toiminnan valtionapupohjaa voimakkaasti.

Kun Aulis Alanen kiinnitti näihin ongelmiin huomiota vuonna 1987, hänen johtopäätöksenä torjuttiin alan piirissä perusteettomana pahansuopaisuutena. Nyt siitä puhutaan niin kuin pitääkin. Tosin Rantanenkin muotoilee lauseensa niin, että ongelma näyttäytyy imperfektissä. Kuitenkin opintokeskusten mahdollisuudet vastata toimintansa sisällöstä ja laadusta ovat em. syistä monessa tapauksessa edelleen kovin rajalliset, mikä on ongelma niiden toiminnan uskottavuuden kannalta.

Rantanen esittää M:n tulevaisuuden peruspilareista neljäkohtaisen jäsennyksen. Tehtävät keskittyvät koulutuksen tasa-arvon turvaamiseen, kansalaisyhteiskuntaa vahvistavaan sivistystyöhön, kansainvälistymisen edistämiseen sekä tietoverkkojen ottamiseen sivistystyön käyttöön.

Opintokeskustoiminnan tulevaisuuden kannalta on erityisen tärkeää se, mitä Rantanen lainaa järjestöllisen sivistystyön arviointia koskevasta opetushallituksen muistiosta: "Sivistysjärjestöjen ja opintokeskusten on 
periaatteessa hyvin mahdollista ryhtyä toimimaan kansalaisyhteiskuntapainotteisessa Suomessa jonkinlaisina sivistyksen verkkoina, moniaalle ulottuvina kehittämisorganisaatioina. Toimintatapoja, organisaatiomuotoja ja vapaan sivistystyön traditiota ajatellen kysymys ei ole edes kovin pitkästä loikasta vaan enemmän muokkauksesta, kehittämistyöstä ja nykyisen verkostomaisen ja monenlaisiin yhteistyösuhteisiin perustuvan toimintakulttuurin systematisoinnista".

Rantasen mukaan TSL on koko olemassaolonsa ajan rakentanut nyt muodissa oleville verkostoitumisen ideoille ja on omiaan toimimaan postmodernissa yhteiskunnassa, joka edellyttää joustavuutta ja kykyä toimia ilman massiivisia kiinteitä rakenteita. Se on aika paljon sanottu, kun ottaa huomioon liikkeen vahvan kollektiivisen perinteen ja massiiviset rakenteet, vaikka TSL on toki tässäkin suhteessa sivistystyön uudistamisen kärkeä.

Suosittelen luettavaksi muitakin tämän ajankohtaisen, joskin hieman epätasaisen teoksen artikkeleita. 